\title{
Vibrio tubiashii sp. nov., a Pathogen of Bivalve Mollusks
}

\author{
H. S. HADA, ${ }^{1}$ P. A. WEST, ${ }^{1}+$ J. V. LEE ${ }^{2}$ J. STEMMLER, ${ }^{1}$ AND R. R. COLWELL ${ }^{1 *}$ \\ Department of Microbiology, University of Maryland, College Park, Maryland $20742^{1}$ and Public Health Laboratory \\ Service Center for Applied Microbiology and Research, Porton Down, Salisbury SP4 OJ6, England ${ }^{2}$
}

\begin{abstract}
The genotypic and phenotypic properties of six strains that were isolated during two unrelated incidents of a bacterial disease of bivalve mollusk larvae were compared with phenotypically similar Vibrio species. The strains of this bivalve mollusk larval pathogen are distinct from other Vibrio spp. phenotypically and as determined by deoxyribonucleic acid-deoxyribonucleic acid hybridization and are described here as Vibrio tubiashii sp. nov. The base composition of the overall deoxyribonucleic acid is 43 to $45 \mathrm{~mol} \%$ guanine plus cytosine. All strains of $V$. tubiashii degrade xanthine and tyrosine extracellularly. Strain ATCC 19109 is designated the type strain of $V$. tubiashii.
\end{abstract}

Tubiash et al. (7) described strains of Vibrio spp. that were pathogenic for the larvae of bivalve mollusks. These organisms were tentatively identified as Vibrio anguillarum and were deposited in the American Type Culture Collection as strains ATCC 19105, ATCC 19106, and ATCC $19109^{\mathrm{T}}(\mathrm{T}=$ type strain). In the last decade, knowledge of the taxonomy of the genus Vibrio has advanced rapidly, and many bacteria that would have been identified as $V$. anguillarum previously can now be allocated to genotypically and phenotypically distinct species, including $V$. anguillarum sensu stricto, Vibrio ordalii, Vibrio nereis, Vibrio fluvialis, Vibrio diazotrophicus, and Vibrio splendidus $(1,9)$.

In a numerical taxonomic study of 237 strains of the Vibrionaceae, including type and reference strains of most of the species of Vibrio and over 50 wild isolates of $V$. anguillarum, strains ATCC 19105, ATCC 19106, and ATCC $19109^{\mathrm{T}}$ were shown to be closely related to one another but phenotypically distinct from $V$. anguillarum and all other Vibrio spp. (10). Recently, Jeffries (3) isolated strains of Vibrio spp. in England which were pathogenic for oyster larvae and were phenotypically similar to the strains which Tubiash et al. isolated from diseased hardshell clams on the east coast of the United States (7).

In view of the potential economic importance of these vibrios in the cultivation of bivalve mollusk larvae, the work described here was undertaken to establish the genetic relationship between the larval bivalve pathogens and phenotypically similar Vibrio spp.

\section{MATERIALS AND METHODS}

Bacterial strains and phenotypic characterization. The strains which we examined and their sources are listed in Table 1 . The methods used for phenotypic characterization of each strain have been described previously $(9,10)$. All preparations were incubated at $25^{\circ} \mathrm{C}$.

DNA extraction. Deoxyribonucleic acid (DNA) was isolated essentially by the methods of Marmur and Doty (5). Bacteria harvested from 2-liter cultures by centrifugation $\left(6,500 \times g, 15 \mathrm{~min}, 5^{\circ} \mathrm{C}\right)$ were washed twice in a solution containing $0.1 \mathrm{M} \mathrm{NaCl}, 0.05 \mathrm{M}$ tris(hydroxymethyl)aminomethane base, and $0.05 \mathrm{M}$ ethylenediaminetetraacetate $(\mathrm{pH}$ 8.1) (TES). The cells were resuspended in TES, incubated with $1 \mathrm{mg}$ of lysozyme (Sigma Chemical Co., St. Louis, Mo.)

\footnotetext{
* Corresponding author.

$\dagger$ Present address: Ministry of Agriculture, Fisheries and Food, Fisheries Laboratory, Burnham-on-Crouch, CMO 8HA, England.
}

per $\mathrm{ml}$ and $50 \mu \mathrm{g}$ of pronase (Calbiochem-Behring Corp., La Jolla, Calif.) per $\mathrm{ml}$ for $30 \mathrm{~min}$ at room temperature, and lysed by adding $6 \mathrm{mg}$ of sodium dodecyl sulfate per ml. A 0.2 volume of TES-saturated, distilled phenol was added, and the mixture was shaken for $30 \mathrm{~min}$; this was followed by centrifugation at $6,000 \times g$ for $15 \mathrm{~min}$. The upper aqueous layer was collected, mixed with $30 \mathrm{ml}$ of a chloroformisoamyl alcohol mixture $(24: 1)$, and centrifuged at $6,000 \times g$ for $15 \mathrm{~min}$ at $5^{\circ} \mathrm{C} ; 2$ volumes of cold $\left(-20^{\circ} \mathrm{C}\right) 95 \%$ ethanol was added to the collected aqueous solution, and the nucleic acid precipitated was spooled onto glass rods. The nucleic acid was dissolved in $0.1 \times \mathrm{SSC}(1 \times \mathrm{SSC}$ is $0.15 \mathrm{M} \mathrm{NaCl}$ plus $0.015 \mathrm{M}$ sodium citrate, $\mathrm{pH} 7.0$ ) and incubated with $250 \mu \mathrm{g}$ of pancreatic ribonuclease (Sigma Chemical Co.) per $\mathrm{ml}$ for $3 \mathrm{~h}$ at $37^{\circ} \mathrm{C}$. A single phenol extraction was followed by three to five chloroform-isoamyl alcohol extractions. The DNA was precipitated by using 2 volumes of $95 \%$ ethanol and then dissolved in $0.1 \times$ SSC. A second precipitation was accomplished by adding 0.1 volume of $2.2 \mathrm{M}$ sodium acetate- 0.01 $\mathrm{M}$ ethylenediaminetetraacetate $(\mathrm{pH} 7.2)$ and 0.6 volume of isopropyl alcohol $\left(-20^{\circ} \mathrm{C}\right)$ while spooling with a glass rod. The spooled DNA was dissolved in 0.1 $\times$ SSC.

Determination of $\mathbf{G}+\mathbf{C}$ content. The purity of each DNA preparation was determined spectrophotometrically. Values of 2.0 for the ratio of optical density at $260 \mathrm{~nm}$ to optical density at $230 \mathrm{~nm}$ and 1.75 to 1.85 for the ratio of optical density at $260 \mathrm{~nm}$ to optical density at $280 \mathrm{~nm}$ were used to indicate a lack of protein and ribonucleic acid contamination. The mean guanine-plus-cytosine $(\mathrm{G}+\mathrm{C})$ content of the DNA was calculated by estimating the midpoint of the optical melting curves (4). The melting temperatures were determined by establishing an absorbance-temperature profile $\left(60\right.$ to $\left.90^{\circ} \mathrm{C}\right)$ at $260 \mathrm{~nm}$ with a Gilford model $2400-\mathrm{S}$ spectrophotometer. Control DNA from Escherichia coli ATCC $11775^{\mathrm{T}}$ was included in all determinations.

DNA-DNA hybridization. Unlabeled DNA was adjusted to a concentration of $10 \mu \mathrm{g} / \mathrm{ml}$ with $0.1 \times$ SSC, denatured by adding 0.1 volume of $1.0 \mathrm{~N} \mathrm{NaOH}$ for $10 \mathrm{~min}$, and chilled in an ice bath. After neutralization with $1.8 \mathrm{M}$ tris(hydroxymethyl)aminomethane hydrochloride-tris(hydroxymethyl)aminomethane base, the DNA was adjusted to a concentration of $5 \mu \mathrm{g} / \mathrm{ml}$ with $3 \times \mathrm{SSC}$, and $10 \mathrm{ml}$ of this solution was gravity filtered through nitrocellulose filters (diameter, 25 $\mathrm{mm}$; pore size, $0.45 \mu \mathrm{m}$; type BA85; Schleicher-Schuell, Dassel, Germany). The amount of filter-bound DNA was estimated by spectrophotometrically measuring the DNA in the filtrate (2). The filters were washed with $10 \mathrm{ml}$ of $3 \times$ SSC, dried overnight at $20^{\circ} \mathrm{C}$, and vacuum dried for $2 \mathrm{~h}$ at 
TABLE 1. Bacterial strains used and their sources

\begin{tabular}{|c|c|c|}
\hline Species & Strain $^{a}$ & Source \\
\hline \multirow[t]{6}{*}{ Vibrio tubiashii } & ATCC 19105 & Hard clam larvae \\
\hline & ATCC 19106 & Oyster spat \\
\hline & ATCC $19109^{\mathrm{T}}$ & Juvenile hard clams \\
\hline & $\begin{array}{l}\text { NCMB } 2164 \\
(=\mathrm{B}-\mathrm{Z})\end{array}$ & Oyster larvae $^{b}$ \\
\hline & $\begin{array}{c}\text { NCMB } 2165 \\
(=B-S S)\end{array}$ & Oyster larvae \\
\hline & $\begin{array}{c}\text { NCMB } 2166 \\
(=\mathrm{B}-\mathrm{TE})\end{array}$ & Oyster larvae \\
\hline Vibrio anguillarum & ATCC $19264^{\mathrm{T}}$ & Diseased cod \\
\hline Vibrio diazotrophicus & ATCC $33466^{\mathrm{T}}$ & Sea urchin \\
\hline Vibrio fluvialis & NCTC $11327^{\mathrm{T}}$ & Human feces \\
\hline Vibrio metschnikovii & ATCC 7708 & \\
\hline Vibrio nereis & $\operatorname{ATCC} 25917^{\mathrm{T}}$ & Seawater \\
\hline Vibrio proteolyticus & ATCC $15338^{\mathrm{T}}$ & Wood borer \\
\hline Vibrio splendidus & ATCC $33125^{\mathrm{T}}$ & Marine fish \\
\hline Vibrio alginolyticus & ATCC $17749^{\mathrm{T}}$ & Mackerel \\
\hline Vibrio cholerae & ATCC $14035^{\mathrm{T}}$ & Human feces \\
\hline Vibrio fischeri & ATCC 25918 & Seawater \\
\hline Vibrio parahaemolyticus & ATCC $17802^{\mathrm{T}}$ & Seafood \\
\hline Escherichia coli & ATCC $11775^{\mathrm{T}}$ & Urine \\
\hline
\end{tabular}

${ }^{a}$ ATCC, American Type Culture Collection, Rockville, Md.; NCMB, National Collection of Marine Bacteria, Aberdeen, Scotland; NCTC, National Collection of Type Cultures, Colindale, England.

${ }^{b}$ See reference 3 .

$80^{\circ} \mathrm{C}$ and a pressure of $15 \mathrm{lb} / \mathrm{in}^{2}$.

In vitro radioactive labeling of DNA was performed by using the nick translation method (6), in which $1.5 \mu \mathrm{g}$ of DNA in $0.2 \mathrm{ml}$ of $0.1 \times \mathrm{SSC}$ was incubated with $0.2 \mathrm{ml}$ of a nucleotide-buffer solution containing $100 \mu \mathrm{M}$ deoxyribosyladenosine triphosphate, $100 \mu \mathrm{M}$ deoxyribosylguanosine triphosphate, and $100 \mu \mathrm{M}$ deoxyribosylthymine triphosphate in $250 \mathrm{mM}$ tris(hydroxymethyl)aminomethane hydrochloride (pH 7.8), $25 \mathrm{mM} \mathrm{MgCl}$, and $50 \mathrm{mM}$ 2-mercaptoethanol and $0.1 \mathrm{ml}$ of $25 \mu \mathrm{M}\left[\alpha-{ }^{32} \mathrm{P}\right]$ deoxycytidine triphosphate (The Radiochemical Center, Amersham, Ill.). The reaction was initiated by adding $0.1 \mathrm{ml}$ of an enzyme solution containing $100 \mathrm{U}$ of DNA polymerase I and $0.02 \mu \mathrm{g}$ of deoxyribonuclease I. After incubation at $15^{\circ} \mathrm{C}$ for $2 \mathrm{~h}$, the mixture was eluted through a Pasteur pipette column containing TES-saturated polyacrylamide (Bio-Gel P-60; Bio-Rad Laboratories, Richmond, Calif.). A series of 10 fractions $(200 \mu \mathrm{l}$ each) were collected and monitored with a Geiger counter to determine the labeled double-stranded DNA peak.

Labeled DNA was hybridized with nitrocellulose-fixed unlabeled DNA by alkaline denaturation (2) of the labeled DNA in PM buffer $(3 \times$ SSC, $0.02 \%$ Ficoll, $0.02 \%$ polyvinylpyrolidone, $0.02 \%$ bovine serum albumin, $0.01 \%$ sodium dodecyl sulfate). Filters were placed in preheated $\left(65^{\circ} \mathrm{C}\right)$ stoppered vials containing PM buffer and denatured labeled DNA and incubated at $65^{\circ} \mathrm{C}$ for $24 \mathrm{~h}$. The filters were removed, thoroughly washed with $3 \times$ SSC, and air dried, and the radioactive counts were determined by using a Beckman model LS-7500 spectrometer and a scintillation fluid containing $4 \mathrm{~g}$ of Omnifluor (New England Nuclear Corp., Boston, Mass.) per liter of toluene.

\section{RESULTS AND DISCUSSION}

There was a high degree of homology between the DNAs from the strains of Tubiash et al. (7) (strains ATCC 19105, ATCC 19106, and ATCC $19109^{\mathrm{T}}$ ) and the DNAs from the strains of Jeffries (3) (strains NCMB 2164, NCMB 2165, and
NCMB 2166), with the degree of reassociation varying from 68 to $98 \%$ (Table 2). No other strain showed more than $26 \%$ reassociation with DNA from strain NCMB 2166. Similarly, when DNA from $V$. anguillarum ATCC $19264^{\mathrm{T}}$ was used as the reference DNA, it had low $(\leq 27 \%)$ degrees of reassociation with the DNAs of strains ATCC 19105, ATCC 19106, ATCC $19109^{\mathrm{T}}$, NCMB 2164, NCMB 2165, and NCMB 2166. These results suggest that the latter six strains are sufficiently related to one another genotypically and sufficiently distinct from other phenotypically similar vibrios to be considered members of a separate species.

It was only possible to study six strains, but these strains were isolated from estuarine areas at least 2,000 miles $(3,218$ $\mathrm{km})$ apart and have been shown to be responsible for collapses of cultures of bivalve larvae $(3,8)$. In view of the potential economic importance of these strains, we believe that a species should be formally described, and we propose that this species be named Vibrio tubiashii. A species description is given below.

Vibrio tubiashii sp. nov. (tu.bi.ash'i.i. L. gen. n. tubiashii named after H. S. Tubiash, who first isolated the organism [7]) cells are gram-negative short rods $(0.5$ by $1.5 \mu \mathrm{m})$ that are straight or curved and motile by means of a single polar flagellum when they are grown in liquid media. The cells do not swarm on solid media, but lateral short-wavelength flagella may be produced. Colonies on marine agar (Difco Laboratories, Detroit, Mich.) are smooth, circular, and offwhite and may be mucoid. Colonies on TCBS agar (Oxoid Ltd., Basingstoke, England) are smooth, circular, and yellow (sucrose fermenting). No pigments are produced, and strains do not luminesce. Sodium chloride is required for growth, the optimum concentration being 1 to $3 \%(\mathrm{wt} / \mathrm{vol})$; strains are not able to grow in $8 \%(\mathrm{wt} / \mathrm{vol}) \mathrm{NaCl}$. Facultatively anaerobic. Acid but no gas is produced from glucose. Kovacs oxidase positive. Catalase positive. Nitrate reduced to nitrite. Chitin, DNA, gelatin, lecithin, starch, Tween 80, tyrosine, and xanthine are hydrolyzed extracellularly, but sodium alginate and elastin are not. Voges-Proskauer nega-

TABLE 2. DNA base compositions and levels of DNA-DNA relatedness of $V$. tubiashii and $V$. anguillarum strains to other strains of $V$. tubiashii and strains of Vibrio spp.

\begin{tabular}{|c|c|c|c|c|}
\hline \multirow{2}{*}{ Test strain } & \multirow{2}{*}{$\begin{array}{c}\mathrm{G}+\mathrm{C} \\
\text { content } \\
(\text { mol\%) }\end{array}$} & \multicolumn{3}{|c|}{$\begin{array}{c}\text { \% Homology using }{ }^{32} \text { P-labeled DNA from } \\
\text { strain: }{ }^{b}\end{array}$} \\
\hline & & NCMB 2166 & ATCC $19109^{\mathrm{T}}$ & ATCC $19264^{\mathrm{T}}$ \\
\hline NCMB 2164 & 43 & 98 & 79 & 27 \\
\hline NCMB 2165 & 44 & 89 & 85 & 22 \\
\hline NCMB 2166 & 43 & 100 & 68 & 27 \\
\hline ATCC 19105 & 44 & 97 & 83 & 18 \\
\hline ATCC 19106 & 45 & 85 & 96 & 19 \\
\hline ATCC $19109^{\mathrm{T}}$ & 45 & 71 & 100 & 15 \\
\hline ATCC $19264^{\mathrm{T}}$ & 45 & 22 & 28 & 100 \\
\hline ATCC $33466^{\mathrm{T}}$ & 44 & 19 & $\mathrm{ND}^{c}$ & ND \\
\hline NCTC $11327^{\mathrm{T}}$ & 48 & 17 & ND & ND \\
\hline ATCC 7708 & 46 & 16 & ND & ND \\
\hline ATCC $25917^{\mathrm{T}}$ & 46 & 19 & ND & ND \\
\hline ATCC $15338^{\mathrm{T}}$ & 50 & 13 & ND & ND \\
\hline ATCC $33125^{\mathrm{T}}$ & 45 & 26 & ND & ND \\
\hline ATCC $17749^{\mathrm{T}}$ & 47 & 24 & ND & ND \\
\hline ATCC $17802^{\mathrm{T}}$ & 47 & 24 & ND & ND \\
\hline ATCC $14035^{\mathrm{T}}$ & 48 & 13 & ND & ND \\
\hline ATCC $25918^{\mathrm{T}}$ & 40 & 19 & ND & ND \\
\hline
\end{tabular}

a Mean of three determinations. The level of accuracy was $\pm 1.5 \%$.

${ }^{b}$ Mean of three determinations. The level of accuracy was $\pm 14 \%$.

${ }^{c}$ ND, Not determined. 
TABLE 3. Characteristics of $V$. tubiashii which differ from strain to strain

\begin{tabular}{|c|c|c|c|}
\hline Trait & $\begin{array}{c}\% \text { of } \\
\text { strains } \\
\text { positive }\end{array}$ & $\begin{array}{c}\text { Reaction of } \\
\text { strain ATCC } \\
\quad 19109^{\mathrm{T}}\end{array}$ & Strains of $V$. tubiashii that are positive \\
\hline Acid from cellobiose & 33 & $t^{a}$ & ATCC 19106, ATCC $19109^{\mathrm{T}}$ \\
\hline Møllers arginine ${ }^{b}$ & 83 & + & ATCC 19105, ATCC 19109 ${ }^{\mathrm{T}}$, NCMB 2164, NCMB 2165, NCMB 2166 \\
\hline \multicolumn{4}{|r|}{ - } \\
\hline DL-3-Hydroxybutyrate & 33 & + & ATCC 19106, ATCC $19109^{\mathrm{T}}$ \\
\hline D-Alanine & 67 & + & ATCC 19105, ATCC 19106, ATCC $19109^{\top}$, NCMB 2166 \\
\hline Melibiose & 50 & + & ATCC 19106, ATCC $19109^{\mathrm{T}}$, NCMB 2165 \\
\hline Putrescine & 17 & - & ATCC 19106 \\
\hline Adenine & 50 & - & ATCC 19105, ATCC 19106, NCMB 2165 \\
\hline Growth at $37^{\circ} \mathrm{C}$ & 33 & - & NCMB 2164, NCMB 2165 \\
\hline \multicolumn{4}{|l|}{ Growth in: } \\
\hline $4 \% \mathrm{NaCl}$ & 83 & + & ATCC 19105, ATCC 19106, ATCC $19109^{\mathrm{T}}$, NCMB 2165, NCMB 2166 \\
\hline $5 \% \mathrm{NaCl}$ & 83 & + & ATCC 19105. ATCC 19106, ATCC $19109^{\mathrm{T}}$. NCMB 2165, NCMB 2166 \\
\hline $6 \% \mathrm{NaCl}$ & 17 & - & NCMB 2166 \\
\hline
\end{tabular}

${ }^{a}+$, Positive; - , negative.

${ }^{b}$ Character useful for differentiating $V$. tubiashii from other species of Vibrio.

tive. Grows on simple mineral media on a variety of organic carbon sources, including glycine, mannose, and galactose but not $D$-sorbitol or $\gamma$-aminobutyrate. Produces $\beta$-galactosidase. Acid is produced from sucrose and D-mannose but not from L-arabinose, arbutin, $m$-inositol, lactose, raffinose, L-rhamnose, salicin, D-sorbitol, or D-xylose. Susceptible to 2,4-diamino-6,7 diisopropylpteridine (agent 0/129) phosphate $(10-\mu \mathrm{g}$ disk) and polymyxin B (50-Iu disk). Not able to decarboxylate lysine and ornithine. Chicken erythrocytes are not agglutinated. Pathogenic for oyster (Crassostrea virginica, Crassostrea gigas, and Ostrea edulis) and clam (Mercenaris mercenaria) larvae. The characteristics which vary among strains are listed in Table 3 . The base composition of the DNA ranges from 43 to $45 \mathrm{~mol} \% \mathrm{G}+\mathrm{C}$.

All strains have been isolated from diseased larvae of clams and oysters.

The type strain is ATCC 19109. The description of the type strain is the same as that given above for the species, and other characteristics are given in Table 3. The base composition of the DNA is 43 to $45 \mathrm{~mol} \% \mathrm{G}+\mathrm{C}$, as determined by thermal denaturation.

Additional characteristics of strains ATCC 19105, ATCC 19106, and ATCC $19109^{\mathrm{T}}$ have been given elsewhere (9). Characteristically, all strains of the species are able to hydrolyze xanthine and tyrosine extracellularly over a 14day incubation period. Although the zone of clearing in these tests may only be below the colony, it is a character that is easy to determine and useful for identification. No other species of Vibrio described so far can degrade xanthine, and tyrosine hydrolysis is restricted to only a few strains (9). Some strains of $V$. tubiashii are also unusual for vibrios in being able to grow on adenine and melibiose (Table 3). In addition, strains of $V$. tubiashii can grow on glycine, are Voges-Proskauer negative, do not produce acid from Larabinose or D-sorbitol, do not agglutinate chicken erythrocytes, and are not able to grow on sorbitol. These features

TABLE 4. Characters useful for distinguishing $V$. tubiashii from phenotypically similar species ${ }^{a}$

\begin{tabular}{|c|c|c|c|c|c|c|c|c|}
\hline Trait & V. tubiashii & V. anguillarum & $V$. nereis & V. fluvialis & V. splendidus biovar 1 & V. ordalii & V. diazotrophicus & V. metschnikovii \\
\hline Luminescence & $-b$ & - & - & - & + & - & - & - \\
\hline Gas from glucose & - & - & - & $\mathrm{V}$ & - & - & - & - \\
\hline Oxidase & + & + & + & + & + & + & + & - \\
\hline Nitrate reduction & + & + & + & + & + & - & + & - \\
\hline Voges-Proskauer & - & + & - & - & - & - & - & + \\
\hline \multicolumn{9}{|l|}{ Acid from: } \\
\hline L-Arabinose & - & V & - & + & - & - & + & - \\
\hline Cellobiose & $\mathrm{V}$ & + & - & $\mathrm{V}$ & + & + & + & $\mathrm{V}$ \\
\hline Salicin & - & - & - & $\mathrm{V}$ & - & V & + & - \\
\hline D-Sorbitol & - & $\mathrm{V}$ & - & - & - & - & - & V \\
\hline Growth on D-xylose & - & - & - & - & - & - & + & - \\
\hline \multicolumn{9}{|l|}{$\begin{array}{l}\text { Extracellular degra- } \\
\text { dation of: }\end{array}$} \\
\hline Casein & + & + & - & + & $\mathrm{V}$ & + & - & + \\
\hline Chitin & + & + & + & + & + & + & - & + \\
\hline DNA & + & + & + & + & + & + & - & + \\
\hline Gelatin & + & + & - & + & + & + & - & + \\
\hline Lecithin & + & V & - & + & + & - & - & + \\
\hline Tween 80 & + & + & - & + & + & - & - & + \\
\hline Tyrosine & + & - & + & V & - & - & - & - \\
\hline Xanthine & + & - & - & - & - & - & - & - \\
\hline
\end{tabular}

${ }^{a}$ Data from references 9 and 10 .

$b_{-}-$, Negative; + , positive; $\mathrm{V}$, variable among strains. 
readily distinguish $V$. tubiashii from $V$. anguillarum, and $V$. tubiashii may be distinguished from other similar species of Vibrio on the basis of the tests shown in Table 4 .

\section{ACKNOWLEDGMENTS}

This research was supported in part by grant DEB-82-08418 from the National Science Foundation, by Public Health Service grant R22 AI 14242 from the National Institutes of Health, and by the National Oceanic and Atmospheric Administration Office of Sea Grant, Department of Commerce, under grant NA81AA-D-00040.

\section{LITERATURE CITED}

1. Baumann, P., L. Baumann, S. S. Bang, and M. J. Woolkalis. 1980. Reevaluation of the taxonomy of Vibrio, Beneckea, and Photobacterium: abolition of the genus Beneckea. Curr. Microbiol. 4:127-132.

2. Gillespie, D., and S. Spiegelman. 1965. A quantitative assay for DNA-RNA hybrids with DNA immobilized on a membrane. J. Mol. Biol. 12:829-842.

3. Jeffries, V. E. 1982. Three Vibrio strains pathogenic to larvae of Crassostrea gigas and Ostrea edulis. Aquaculture 29:201-226.

4. Mandel, M., L. Igambi, J. Bergendahl, M. L. Dodson, and E.
Scheltgen. 1970. Correlation of melting temperature and cesium chloride buoyant density of bacterial deoxyribonucleic acid. J. Bacteriol. 101:333-338.

5. Marmur, J., and P. Doty, 1962. Determination of the base composition of deoxyribonucleic acid from its thermal denaturation temperature. J. Mol. Biol. 5:109-118.

6. Rigby, P. W. J., M. Dieckmann, C. Rhodes, and P. Berg. 1977. Labelling deoxyribonucleic acid to high specific activity in vitro by nick translation with DNA polymerase I. J. Mol. Biol. 113:237-251.

7. Tubiash, H. S., P. E. Chanley, and E. Leifson. 1965. Bacillary necrosis, a disease of larval and juvenile bivalve mollusks. I. Etiology and epizootiology. J. Bacteriol. 90:1036-1044.

8. Tubiash, H. S., R. R. Colwell, and R. Sakazaki. 1970. Marine vibrios associated with bacillary necrosis, a disease of larval and juvenile bivalve mollusks. J. Bacteriol. 103:272-273.

9. West, P. A., and R. R. Colwell. 1983. Identification and classification overview, p. 285-364. In R. R. Colwell (ed.), Vibrios in the environment. John Wiley \& Sons, Inc., New York.

10. West, P. A., J. V. Lee, and T. N. Bryant. 1983. A numerical taxonomic study of species of Vibrio isolated from the aquatic environment and birds in Kent, England. J. Appl. Bacteriol. 55:263-282. 